\title{
PARTICIPATION OF CITIZENS IN PUBLIC FINANCIAL DECISION-MAKING IN SERBIA
}

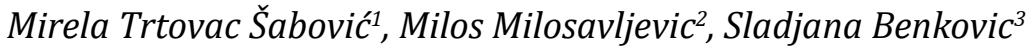

\begin{abstract}
Participation in the local public finance decision-making process in Serbia is not a new concept as it was implemented even during the 'Titoistic' period. However, direct participation is still in an infant phase altogether with the low interest of citizens in participating in local financial decision-making procedures. The aim of this paper is to explain the main types of civic participation in the local financial decisionmaking process (i.e., referendum voting on self-imposed contribution, participatory budgeting, and civic crowdfunding) and to focus on the main factors that lead to a low participation of citizens in such processes. Additionally, the article analyses how these factors affect general mistrust in politics and society. For this purpose, a total of $N=421$ citizens were interviewed. Using the principal component analysis, the following three main components for low participation were defined: 1) lack of knowledge, 2) lack of interest, and 3) lack of political will. Thereafter, using the regression analysis, the study confirmed that the first two components are statistically significant predictors for mistrust in politics and society.
\end{abstract}

KEY WORDS: Alternative public financing, Self-imposed contribution, Participatory budgeting, Civic crowdfunding, Principal Component Analysis, Serbia.

\section{INTRODUCTION}

Nowadays, providing the existing public services and reaching for the new ones with a reluctance to manage budgets are challenging all local governments around the world. New needs and requirements are increasing traditional sources of financing, leading local administrations to search for alternative sources of financing. New financing strategies include green bonds, social impact bonds, privatization (Singla, Shumberger, Swindell, 2019), public-private partnerships (Benkovic, Krivokapic, Milosavljevic, 2015), and many others.

\footnotetext{
${ }^{1}$ Faculty of Organizational Sciences, University of Belgrade, Jove Ilica 154, 11000 Belgrade, Serbia. E-mail: mirela.sabovictrtovac@gmail.com, ORCID: 0000-0002-0183-0749.

${ }^{2}$ Faculty of Organizational Sciences, University of Belgrade, Jove Ilica 154, 11000 Belgrade, Serbia. E-mail: milos.milosavljevic@fon.bg.ac.rs, ORCID: 0000-0002-4965-4676.

${ }^{3}$ Faculty of Organizational Sciences, University of Belgrade, Jove Ilica 154, 11000 Belgrade, Serbia. E-mail: sladjana.benkovic@fon.bg.ac.rs, ORCID: 0000-0002-8798-916X.
} 
Until now, many academic radars have been focused on new classes and instruments used to finance local infrastructure, goods, and services. However, a simple increase in taxes, municipal debts, or the enforcement of any other type of tax on citizens or enterprises without their direct support, approval or cooperation now seems less realistic (Sedlitzky, Franz, 2019).

Citizencentrism as a concept requires a constant review of attitudes and opinions towards public services (Cicvaric Kostic et al, 2013). Innovation in both funding and citizens' participation is necessary for the sustainable operation and investments in local services. Public administration is not synonymous with innovation, but (Radonic, Milosavljevic, 2019), some progress has recently been made at the global level (Fung, 2015) and national level (Serbian).

In the post-world period, participation in the public financial decisionmaking at the local level in Serbia was introduced during the "Titoistic" period. The concept of self-imposed contribution and 'working actions' was extensively used for the reconstruction and development of Serbia, a part of then Yugoslavia (Milosavljevic, Spasenic, Benkovic, 2022). True participation was introduced in the last few decades in the form of participatory budgeting. However, only a few municipalities implemented this concept of participatory budgeting, mostly as a part of the EU projects (Milosavljevic et al., 2020). Finally, a special attention in 2021 was paid to a modern concept of the participation of citizens in financial decision-making processes when the first civic crowdfunding project was initiated and implemented in Serbia (Milosavljevic et al., 2021).

Although these three concepts (self-imposed contribution, participatory budgeting and civic crowdfunding) of participation in financial decision making in local communities can alleviate some of the administrative issues and overcome financial obstacles, and citizen activism aimed at direct participation stays rather non-utilized. The main barriers and obstacles for the citizens' involvement and low participation in budgetary and other financial issues at the local level remain an unsolved puzzle. This paper aims to empirical research of the main factors and the forces omitting the citizens' engagement in local-level financial decisions. The specific objectives of this study are as follows:

- empirically exploring the main factors causing an insufficient engagement of citizens participating at the local-level public financial decision-making processes; and

- empirically examining the ways how these factors affect the mistrust in politics and society. 
In the authors' opinion, such studies have never been carried out. Although a wide range of evidence is mainly aimed at finding the main reasons for direct democracy, only a few studies examined, investigated and studied the main factors and predictors of this phenomenon (Zepic, Dapp, Krcmar, 2017). In terms of methodology, most of the similar studies are theoretical rather than empirical (Sintomer, Herzberg, Röcke, 2008). Finally, in terms of geographical context, there is a lack of research carried out in developing economies with none conducted in Serbia.

The paper is structured in the following chapters. The introduction presents the matter of participation in financial decision-making process at the local public level as a topic of this paper. Chapter 1 (Literature Review) reviews the dominant participation models in the local financial decisionmaking process (self-imposed contribution, participatory budgeting, and civic crowdfunding). Following Chapter 2 (Methodology) elaborates on the methodology applied (the development of the research instrument, sampling procedure, data collection and processing). Consecutive Chapter 3 (Findings) delineates the results and is interlinked to Chapter 4 (Discussion), which contextualizes the main findings and explains contributions and implications of the research introduced in this paper. Finally, the last chapter provides concluding remarks along with the main research limitations and further recommendations.

\section{LITERATURE REVIEW}

The concept of participation is still vague and "covers different models and tools that should have enhanced political participation of the citizens" (Minárik, 2020, p. 29). This chapter addresses the current situation and historical development of citizen participation in financial decision-making processes at the local level with the aim of explaining the spatial and socio-political context of the study. In this part, three main types of direct citizen participation implemented in Serbia are described: 1) self-imposed contribution, 2) participatory budgeting, and 3) civic crowdfunding.

Although citizens of Serbia utilise various options for direct participation in the financial decision-making process at the local level, their participation has not been high and the public interest in such projects has been modest. Accordingly, this Chapter reviews also the literature related to the eventual reasons for low participation of citizens in participatory forms of financial decision-making. On the basis of this literature review, two hypotheses are set. 


\subsection{Main types of participation in financial decision making at the local level in Serbia}

Serbia is not a leader in public sector innovativeness (Milanovic, Milosavljevic, Milosevic, 2019), transparency (Milosavljevic, Milanovic, Benkovic, 2017), or efficiency (Milosavljevic, Dobrota Milanovic, 2018) at both central and local government levels. Citizens' participation in governance in general, and financial decision-making processes certainly require these qualities of public management.

However, from a historical point of view, some rudimental versions of the participation of citizens in the decision-making process were present around in Serbia even during the communist period. This fact refers to the self-imposed contribution particularly, as this way of financing was used for the reconstruction and development of Serbian economy throughout the second half of $20^{\text {th }}$ and the beginning of $21^{\text {st }}$ century. In this chapter, different models of 1) self-imposed contribution, 2) participatory budgeting, and 3) crowdfunding are explained and illustrated.

The first one, a self-imposed contribution is a specific type of financial levy for which citizens decide on a referendum and is typical for local self-governments. Aimed at gaining better living conditions, residents of a certain municipality (or even a lower level of local communities, the socalled 'mesna zajednica') may be willing to pay an additional fiscal levy in addition to the ordinary taxes (Podlipnik, Ilić-Popov, 2018). Citizens vote on a self-imposed contribution in a referendum. A detailed regulation of such referendums in Serbia is provided for in Articles 87 to 97 of the Local Self-Government Act (Law on Local Self-Government, 2007). This legal obligation is a special decision that creates material obligations, both for those voting in referendum and for those citizens who do not vote in the referendum. The fact of voluntary participation is still considered as very important (SKGO, 2006, p. 47). This fiscal levy does not necessarily imply cash transfers from citizens to local budgets. In fact, this contribution can be delivered in-kind (goods, labour, transportation, or any other services). As such, this fiscal levy is seldom used for the common needs of the population in rural and suburban settlements (SKGO, 2006, p. 47).

The procedure for the introduction of self-imposed contribution encompasses three phases: 1) The municipal assembly submits a program that determines the sources, purpose, and manner of providing total funding for the self-imposed contribution; 2 ) The municipal assembly determines the proposal of the decision on the introduction of the self-imposed contribution; 
and 3) The citizens decide on the proposal of the decision directly, by secret ballot or in person with a signature, and the decision is made if the majority of the total number of citizens from the area to which it refers vote for it.

There were several examples of calling a referendum in Serbia in the last few years, such as the case Žitište, where a referendum for self-contribution was called in 2019 (for a period from 1.5.2019 to 30.04.2024). Also, another example of a successful referendum held on the introduction of selfcontribution is the one held with the local community "Lukićevo" (adopted for the period from 01.01.2015 until 31.12.2024).

"Participatory budgeting is a decision-making process in which citizens deliberate and negotiate over the distribution of public resources" (Silva, Morais, 2011, p. 3184). Thus, it enables citizens to allocate directly the taxpayer's money (Jabola-Carolus, 2017). Ever since the first case of implementing the participatory budgeting was the Brazilian city of Porto Alegre in the late 1980s, and since then the concept of participation in financial decision-making in local administrations has been attracting a lot of academic and practical attention.

Participatory budgeting is implemented in the form of (i) offline versions (public assemblies between local governments and citizens), (ii) online versions using ICT tools to interact with citizens, for instance, receiving project proposals through a web portal or balloting via SMS votes, and (iii) hybrid versions, when citizens can participate both online and in public assemblies (Ewens, van der Voet, 2019).

Most of the cases of participatory budgeting in Serbia are explained by detail in Milosavljevic, et al. (2020). In a nutshell, the process of participatory budgeting is not founded in law, the diffusion of the cases is low as only a few municipalities (in one case a sub-municipal level) have conducted participatory budgeting up to now with municipal funds the main source of finance, ranging from 0.05 to $0.39 \%$.

Finally, crowdfunding- the third model, in general, is a fundraising technique, which allows businesses, physical persons, or non-governmental organizations to obtain capital from a large number of individuals from the general public, so-called the 'crowd' (Macht, Weatherston, 2014). The main characteristic is the provision of funds through small donations or sponsorship by individuals from various online communities or organizations that identify themselves with the specific project seeking the funding (Hemer, 2011).

A civic crowdfunding is a specific class of crowdfunding (Stiver et al., 2014). The main difference from 'standard' crowdfunding projects is the 
aim: civic crowdfunding projects are directed towards contributing to community development (Carè et al., 2018) and the outputs of such project are various community or quasi-public assets (Davies, 2014). The secondary differences to the other classes of crowdfunding are in terms of the main platforms, online communities, participants, sponsors, narratives in the campaigns, etc. (Lee et al., 2019; Wenzlaff, 2020).

Civic crowdfunding has been implemented in a considerable number of projects around the world (Brent, Lorah, 2019). As for the case of Serbia, by simply browsing through the main international crowdfunding platforms (Kikstarter, IndiGoGo) and specialized civic crowdfunding platforms (Citizinvestor, ioby, Spacehive), none of the cases were recorded in Serbia (Milosavljevic et al., 2021). A specialized platform for a civic crowdfunding competition was launched in 2021 by the National Alliance for Local Economic Development in cooperation with "Loud Crowd" and supported by the German Federal Ministry for Economic Cooperation and Development (BMZ). Approximately five thousand participants joined the conference and funded the winning project from this competition. However, larger-scale projects are still expected.

Although citizens are in the focus of the financial decision-making process (particularly those related to budgeting), the number of citizens active participants in such programs or projects - is still low. The common sense could lead to the conclusion that this might be connected to generally low turnout rates at elections (i.e. turnout stood at a record low at the parliamentary elections held in 2021, the lowest since the introduction of the multiparty system in Serbia in 1990). In addition to this, other economic or political factors related to the low turnout are emphasized in other studies (Pavlović, 2019; Nastić, 2020).

\subsection{The reasons for the low participation of citizens in the forms of participatory financial decision-making}

Several studies analyse the reasons for the low engagement of citizens in participatory budgeting processes around the globe. For example, the main reasons listed in a quantitative study conducted by Yang and Pandey (2011) include the presence of elected representatives, transformational leadership, and the structures of the target organization and citizen characteristics, which include the competence and representativeness of the citizens involved. On the other hand, Pandeya and Shrestha (2016) claim that the main factors of effective citizen participation are: (a) administrative 
factors, for example, institutional and policy frameworks, organizational characteristics, bureaucratic responsiveness, and participation mechanisms; (b) factors related to the citizens involved, for example, how representative and competent they are; and (c) civil society factors, for example, links within community, capacity, and representativeness.

Apparently even in the digitalized context, citizen e-participation remains low. ICT technologies and digitalization are often advocated as a panacea to citizen sourcing and active participation (Schmidthuber, Hilgers, 2017). In some cases, e-participation indeed provides a solution for strengthening e-democracy on the local government level (Mærøe et al., 2020). From a grand scheme of things, municipalities applying the e-Participatory Budgeting programs hold fewer face-to-face meetings in their participatory budgeting programs. Cities with greater administrative capacity, as measured by decentralized management scores (IGD), hold more meetings in their face-to-face participatory budgeting programs than do the cities with less capacity (Touchton, Wampler, Spada, 2019).

Technology might decrease the cost, simplify the process, or save time for both the administration and citizens. However, it would hardly increase participation, as most reasons are based on lack of knowledge, lack of prerequisites provided, no interest or refusal to participate in local financial decision-making processes (Zepic, Dapp, Krcmar, 2017).

As explained in the previous subchapter, although Serbian citizens have an opportunity to directly participate in financial decision-making process at the local level, the actual number of citizens who actively use this opportunity is still low. One explanation for this phenomenon may be that participation projects are "imported" from Western democracies and could not be well suited to the Serbian public administration system (Milosavljević et al, 2020).

\subsection{The political and societal effects of low participation}

Higher citizen turnouts would ultimately improve democratic capacities, as implied in a stream of research based on a so-called 'participation hypothesis.' The participation hypothesis posits that participation in any democratic activity encourages people to engage in other civic activities (Gastil, Xenos, 2010; Boulianne, Chen, Kahane, 2020). This stands for participation in financial matters and issues. For example, some new empirical studies have shown a positive causality between participatory budgeting participation and probability of individuals voting in political 
elections (Johnson, Carlson, Reynolds, 2021). In short, the participation hypothesis deduces that if citizens are actively involved in some sort of deliberate democratic process, they may be more active in other forms of political life, and ceteris paribus.

This ceteris paribus supposition refers to the second aim of this research - the relationship between factors (Lack of knowledge on participation, Lack of interest in participation, Lack of political will) and (mis)trust in politics and society.A number of recent studies have examined the relationship between (non-)participation and (mis)trust in politics and society. Swaner (2017) claims that the trust in elected officials can be improved when residents determine how to spend the public budget. Trust and mistrust, as inferred by Wilkinson et al. (2019), play pivotal role in progressive, effective and trustful participation and vice versa. Kim (2014) argues that effective participation is an antecedent of general public trust in politics. To sum up, the main supposition of previous studies (Swaner, 2017; Wilkinson et al., 2019; Kim ed., 2014) is that participation in financial decision-making processes positively affects trust in politics and society. This paper extends this supposition by claiming that insufficient engagement of citizens in participatory forms of financial decision-making leads to mistrust in politics and society.

\section{METHODOLOGY}

This chapter delineates 1) the research model; 2) the research instrument, variables, measures; 3 ) the sampling procedure; and 4) the data collection and data processing.

The research model of this research follows the research objectives to statistically analyse the main barriers for the participation in financial decision-making processes by reducing them to statistically significant factors, and to examine the influence of such factors in general mistrust in political system and society. Accordingly, two hypotheses were established:

- H1: Different factors of insufficient engagement of citizens in public financial decision-making processes have patterns in behaviour and can accordingly be reduced to principal drivers of low participation; and

- H2: The factors of insufficient engagement of citizens in public financial decision-making processes (Lack of Knowledge, Lack of Interest, and Lack of Political Will) positively affect mistrust in politics and society. 
The research is based on primary data collected through the questionnaire specifically designed to address the purpose of this research. The questionnaire was in an electronic form (Google forms).

The questionnaire had two distinct sections. Section 1 was intended to collect demographic characteristics of respondents - age, sex, general knowledge of public financing processes, and awareness of specific forms of participation in financial decision-making at the local level.

Section 2 was largely based on the study conducted in German cities and examined the main reasons for the refusal of citizens to participate in participatory budgeting processes (Zepic, Dapp, Krcmar, 2017). Variables were structured in three intuitive groups:

1) Knowledge of participation in financial decision making (KNWL1 Knowledge of participation in financial decision-making; KNWL2 - No time to get information on participation; KNWL3 - Processes are too complicated; KNWL4 - No specific ideas on what to suggest or vote for);

2) Interest in participation in financial decision-making (INTR1 - No personal concern, INTR2 - No interest in participation in general, INTR3 - No interest in public finances in general. INTR4 - No interest in participatorybased matters, INTR4 - Overall satisfied with politics, INTR6 - Already participating through other channels, such as civic activism, etc.); and

3) Refusal to participate due to lack of political will (WILL1 - The given recommendations will not be implemented, WILL2 - Complications with registrations for participatory forms of financial decision-making, WILL3 Refusal to support political processes in general, WILL4 - Negative attitude towards any increase in the public expenditures).

Section 3 aimed at collecting evidence on mistrust in politics and society. For this purpose, the items of trust given in Švaljek, Rašić Bakarić and Sumpor (2019) were reverted.

As for the sampling procedure, this research aimed to collect evidence from non-participants in three different forms of citizen participation in financial decision-making. More than 40 cities and municipalities in Serbia with a population of approximately 1.2 million citizens have conducted one out of three forms of participatory financial decision-making (self-imposed contribution, participatory budgeting, or civic crowdfunding). Since the total population is unknown (in terms of the names and contacts of the persons who participated or decided not to participate in financial decision-making processes), the research was based on the snowball sampling technique (see Radonic, Vukmirovic, Milosavljevic, 2021). The questionnaires were coded and actively controlled in order to decrease potential invasive sub-clustering 
within different demographic groups. In total, 421 valid responses were collected. This means that the sample size is not sufficient to be nationally representative but sufficient for preliminary findings regarding the objective of the research. This will be more excessively discussed in the conclusion of the paper.

Data was collected in the period May-June 2021 and were entered in SPSS v.23 and accordingly analysed. First, a pre-analysis was conducted including frequencies and descriptive statistics (means and standard deviations). For the purpose of dimension reduction, a Principal Component Analysis (PCA) was made. PCA is a well-known multivariate approach intended at converting a number of individual correlated variables into a single measure - factor. The new variable is usually named after a principal component (see Mahmoudi et al., 2021). For the examination of interdependence among the observed variables, a correlation analysis (Pearson moment correlation) was applied and for model testing, OLS regression analysis applied.

\section{FINDINGS}

In this chapter, the results of the empirical study are delineated by presenting the sample features, pre-analysis, and hypotheses testing.

A total of 421 participants correctly filled out the questionnaire. The sample size was sufficient to derive valid statistical conclusions. However, it does not imply that the study results can be generalized without any judicious judgements, as thoroughly explained in the conclusion. For the gender split, the sample was disproportionate as $63.4 \%$ were female. The average age of respondents was 31.32 years. The majority of respondents were aware of various forms of participation in financial decision-making in their local communities (77.9\%), whereas $22.1 \%$ did not know that they could participate in either referendum for self-imposed contributions, participatory budgeting, or civic crowdfunding projects. The respondents claimed that they are aware of public financial processes in general (mean $=3.556$, STD $=1.131$ ).

Before testing hypotheses, a pre-analysis was conducted, including descriptive statistics and PCA. The results are given in Table 1 and it shows that the respondents marked the lack of knowledge as the most important factor affecting their modest interest in participating in financial decisionmaking processes at the subnational level $(n=4.646, S T D=0.691)$. On the other side, respondents marked that they were generally interested in participation in processes such as participatory budgeting $(n=2.622$, STD, STD $=1.088)$. 
Table 1: Descriptive Statistics for Individual Items and Principal Component Analysis

\begin{tabular}{|c|c|c|c|c|c|c|c|c|}
\hline & \multicolumn{2}{|c|}{ Descriptives } & \multicolumn{6}{|c|}{ Principal Component Analysis } \\
\hline & Mean & STD & Extr. & Comp. & KMO & $\begin{array}{r}\text { Bartlett, } \\
\text { Extrac }\end{array}$ & $\begin{array}{l}\text { igenvalues a } \\
\text { on Sums }\end{array}$ & \\
\hline \multicolumn{9}{|c|}{ Component 1: Lack of knowledge on participation } \\
\hline KNWL1 & 3.739 & .943 & .560 & .748 & KMO & .642 & Eigenvalue & 1.723 \\
\hline KNWL2 & 4.070 & .967 & .473 & .688 & Bartlett & 135.28 & $\begin{array}{c}\% \text { of } \\
\text { variance }\end{array}$ & 43.07 \\
\hline KNWL3 & 4.646 & .691 & .224 & .473 & df & 15 & & \\
\hline KNWL4 & 3.653 & 1.093 & .467 & .683 & Sig. & .000 & & \\
\hline \multicolumn{9}{|c|}{ Component 2: Lack of interest in participation } \\
\hline INTR1 & 2.622 & 1.088 & .637 & .798 & KMO & .840 & Eigenvalue & 2.987 \\
\hline INTR2 & 3.722 & .987 & .347 & .589 & Bartlett & 690.12 & $\begin{array}{c}\% \text { of } \\
\text { variance }\end{array}$ & 49.79 \\
\hline INTR3 & 3.866 & .922 & .286 & .534 & df & 6 & & \\
\hline INTR4 & 2.886 & 1.069 & .671 & .819 & Sig. & .000 & & \\
\hline INTR5 & 2.904 & 1.086 & .501 & .708 & & & & \\
\hline INTR6 & 2.962 & 1.104 & .546 & .739 & & & & \\
\hline \multicolumn{9}{|c|}{ Component 3: Lack of political will } \\
\hline WILL1 & 2.866 & 1.206 & .531 & .729 & KMO & .653 & Eigenvalue & 1.906 \\
\hline WILL2 & 4.068 & 1.066 & .661 & .813 & Bartlett & 235.83 & $\begin{array}{c}\% \text { of } \\
\text { variance }\end{array}$ & 47.66 \\
\hline WILL3 & 3.075 & 1.169 & .603 & .777 & df & 6 & & \\
\hline WILL4 & 4.104 & .938 & .111 & .333 & Sig. & .000 & & \\
\hline \multicolumn{9}{|c|}{ Component 4: Mistrust in politics and society } \\
\hline MTRU1 & 4.349 & .829 & .388 & .623 & KMO & .643 & Eigenvalue & 1.819 \\
\hline MTRU2 & 4.518 & .754 & .573 & .757 & Bartlett & 181.23 & $\begin{array}{c}\% \text { of } \\
\text { variance }\end{array}$ & 45.48 \\
\hline MTRU3 & 4.223 & .817 & .596 & .772 & df & 6 & & \\
\hline MTRU4 & 3.422 & 1.062 & .262 & .512 & Sig. & .000 & & \\
\hline
\end{tabular}

Source: The authors' calculation

Regarding factor loadings as shown in Table 1, all the components were loaded into intuitively defined factors with an Eigenvalue threshold of 1 (1.723, 2.987, 1.906 and 1.819 respectively). The Eigenvalues as such are vector constructs aimed at representing larger matrices. When the Eigenvalue is higher than one, it indicates the number of factors which 
should be retained. Consequently, $\mathrm{H} 1$ was confirmed and it was proved that different factors prove their patterns and can accordingly be reduced to principal drivers of low participation in financial decision-making processes at the subnational level.

To examine the interdependence between the conducted factors, the correlation analysis was required. The obtained results are in Table 2 and indicate several statistically significant $(\mathrm{p}<.000)$, but these correlations range from low to moderately high correlations. The ones that particularly attract attention here are the ones between the independent variables (Lack of Knowledge, Lack of Interest, and Lack of Political Will) and the dependent one (Mistrust in Politics). All relationships were statistically significant, but low to moderate $\left(b_{1}=0.465, b_{2}=0.353\right.$ and $\left.b_{3}=283\right)$.

Table 2: Correlation Matrix and Regression Analysis

\begin{tabular}{|c|c|c|c|c|c|c|c|c|}
\hline & \multirow{2}{*}{\multicolumn{3}{|c|}{$\begin{array}{l}\text { Correlation } \\
\text { matrix }\end{array}$}} & \multicolumn{5}{|c|}{$\begin{array}{l}\text { Regression analysis } \\
\text { Dep. Variable: Mistrust }\end{array}$} \\
\hline & & & & \multicolumn{2}{|c|}{$\begin{array}{l}\text { Unst. } \\
\text { Coeff. }\end{array}$} & \multicolumn{3}{|l|}{ St. Coeff. } \\
\hline & 2 & 3 & 4 & B & SE & $\beta$ & $\mathbf{T}$ & Sig \\
\hline (Constant) & & & & .000 & .043 & & .000 & 1.000 \\
\hline L. of Knowl. & $.480^{* *}$ & $.413^{* *}$ & $.465^{* *}$ & .381 & .049 & .381 & 7.739 & .000 \\
\hline L. of Inter. & & $.663^{* *}$ & $.353^{* *}$ & .157 & .060 & .157 & 2.613 & .009 \\
\hline L. of P/Will & & & $.283^{* *}$ & .021 & .058 & .021 & .370 & .712 \\
\hline \multicolumn{9}{|l|}{ Mistr. in Pol. } \\
\hline$* \mathrm{p}<.05$ & & & & $\mathbf{R}$ & .488 & SE & .8 & \\
\hline \multirow[t]{2}{*}{${ }^{* *} \mathrm{p}<.00$} & & & & $\mathbf{R}^{2}$ & .238 & $\mathbf{F}$ & 43 & 52 \\
\hline & & & & Adj. $R^{2}$ & .233 & Sig. & & \\
\hline
\end{tabular}

Source: The authors' calculation

Table 2 also shows the results for the regression analysis, where $\mathrm{R} 2=0.238$ means that the model explained $23.8 \%$ of variability of the dependent variable. It implies that three examined independent variables (Lack of Knowledge, Lack of Interest, and Lack of Political Will) explain nearly one quarter of the variability in mistrust in politics.

Table 2 also displays the effects of individual predictors. As indicated by betas and p-values, two out of three variables are solid individual predictors (Lack of knowledge: Beta=.381, p<0.00; Lack of Interest: Beta $=.157, p<0.05$ ), whereas Lack of Political Will is statistically insignificantly contributing to 
the overall model. As seen through $\mathrm{H} 2$, the research confirmed that Mistrust in Political System can be explained by the lack of knowledge and lack of political will.

\section{DISCUSSION}

In this section, the study findings are contextualized. In particular, the key findings and contributions of the results to the general theory are explained, and afterwards, the main implications of the study are specified providing recommendations for both scholars and practitioners.

\subsection{Key findings and Contributions}

Citizens' participation in policy-making, with a special emphasis on involving citizens in the planning, implementation, and monitoring the budget, is one of the main pillars of successful democratic societies. From a broader perspective, this research confirms that citizens participation in financial decision-making processes is still developing in Serbia (Milosavljevic, Spasenic, Benkovic, 2022).

Most of the current studies claim that historical background is a paramount factor that affects the participation of Serbian citizens in policymaking (Blagojević, Perić, 2021). On the contrary, this paper proves that the most important reason for the insufficient number of participants in financial decisions is insufficient knowledge about public financial processes. This finding can be alternatively explained by using the conclusions of the study conducted by Đulabić and Jerinić (2021). Namely, they compared two cases of participation of citizens in local public affairs by using two countries with similar historical background - Serbia and Croatia. They demonstrate a number of differences and find Croatia to be more advanced in terms of the participation of citizens in public affairs. The budgetary process and language used in the communication appear overcomplicated for citizens, particularly phenomena such as budget preparation, budget classifications, cash accounting basis, fiscal system, and the way of distribution of public revenues between different levels of government. All this results in a citizen feeling to be insufficiently competent to participate in the budgeting process and in the disinterest of citizens in this matter.

As the results of this research indicate, the interest in public financial processes is moderate. This might be explained by viewing the budget as a political document - an expression of economic and fiscal policy and 
priorities of local government. The attitude of citizens is that the local budget reflects the interests of important political actors, primarily political parties, thus neglecting the real needs of citizens. All this results in citizens' lack of confidence in local authorities, fear of manipulation, disturbed relations, mistrust among interest groups, the feeling that citizens have not their "place at the table" and that their vote has no impact on the decisions of political leaders. This is to claim that empowerment of participants is key to good governance agenda, which is in line with other researches made on participatory forms of public decision-making (Cabannes, Lipietz, 2017).

\subsection{Implications and Recommendations}

The current level of knowledge of citizens about the public budget and their opportunities to participate in the budgeting process can be improved by better communication and involvement (inviting) the media to all sessions and meetings, organizing appropriate campaigns to expand knowledge and understanding of the budget process, preparing simple forms of complex parliamentary decisions, by creating individual proposals, pointing out the problems and possible ways of overcoming, monitoring the implementation of the approved projects, and encouraging the citizens to actively participate (SKGO, 2006). A significant step forward in increasing the transparency of public finances at the local level and contributing to citizens in terms of insight into public spending planning, is the public budget portal "Open Budgets". This portal provides the users with a simple and easy understanding of the budget of cities and municipalities in Serbia (The Office for Information Technologies and eGovernment of the Republic of Serbia, 2021). The map shows the cities and municipalities that have so far released their budgets in the open data format. This platform allows the users to get an insight into planned budget revenues and expenditures, where budget revenues are presented by categories and groups, and expenditures are presented by programs and economic classification. In $2020,48 \%$ of municipalities in Serbia released a report on this portal.

However, the lack of civic initiatives or ignoring them and the lack of serious control are the key challenges that led to the establishment of the Public Finance Oversight Coalition in 2005, which actively promotes civic oversight of public finances through advocacy campaigns (Spiric, 2010). An increase in the interest of citizens to participate in the process of public budgeting, and expressing a political will for it, is achieved through sending a budget letter by the mayor to citizens, i.e. for surveying the citizens (web, 
service centre, local community, in the pedestrian zone), organizing public hearings, organizing budget forums and round tables. By organizing public hearings, citizens are informed about the possibilities of voting for financing of certain projects, about the possibilities of civic crowdfunding, self-imposed contribution, about the budget-allocated funds. Only the transparency of the budget planning and spending process may lead to constructive proposals from experts, but also from the widest possible public, giving information on how to achieve a more efficient, high-quality, and economical way of using public funds aimed at achieving the public goals. Also, in all this, the cities and municipalities assemblies play a great role in Serbia, that is, mainly councillors who are representatives of citizens, political parties, but also local self-government bodies. They should be involved in the process from the very budget preparation stage. This requires councillors to be sufficiently trained and aware how to participate in the budget process, to fully contribute in proposing the highest priority projects, and control the role in the budget approval and execution process.

\section{CONCLUSION}

Participation in financial decision-making at the local level attracts a lot of academic attention today. The aim of this paper was to contribute to the evolving body of knowledge on this topic. First, this study identified three main types of participation of citizens in financial decision-making in Serbia: 1/ self-imposed contribution, 2/ participatory budgeting, and 3/ civic crowdfunding. Second, this study narrowed the main factors for low participation in financial decision-making to the following factors: $1 /$ lack of knowledge about participation in financial decision-making, 2/ lack of interest in participation, and 3/ lack of political will. Consequently, policy makers and decision makers in Serbia should pay their special attention to development of the educational system (both formal and informal) that would bring the public financial system closer to citizens and improve their interest in direct participation. Finally, this research showed that two factors (lack of knowledge about participation in financial decision-making and lack of interest in participation) affect mistrust in politics and society in general.

Although this study brings about new findings in the topic, methods used, and geography considered in the research, it has a number of limitations. First, the research applies a relatively small number of variables to explain a complex phenomenon of low participation in participatory forms of 
financial decision-making at the local (or any other governmental) level. This opens up an avenue for further research. Some of these variables, which could potentially be examined in follow-up studies, could go from a lowtension set of factors (i.e., specificities of projects proposed for participatory budgeting) to high-tension factors, such as the possible effects of conspiracy mentality.

Second, the sample used in this research has twofold flaws. It is not representative in nation terms since the total number of respondents was $\mathrm{N}=421$. This implies that broad generalization of the conclusions can be prudent and speculative. Also, the sample is based on a snowball sampling technique, which has potential downsides. As much as we controlled for any potential invasive sub-clustering within certain demographic groups, we could not control for all the demographic features. This is particularly important for the political attitude of respondents (since we might have captured only attitudes of political opposition from Serbian municipalities). It would be advisable for other further studies to use a case-study methodology with data from smaller number of municipalities (or local communities), and to collect more insightful and qualitative comments.

Third, the study is very geographically limited. Since much of the participatory forms of decision-making are of a rather new date, Serbia does not share too many similarities with other countries. The early forms of selfimposed contribution were the same among the former Yugoslav countries, and some findings from this research might be generalized to this region. The extension of the results to all post-communist countries or to Europe as a whole would be nothing more than a judicious judgement.

\section{REFERENCES}

BENKOVIC, S., KRIVOKAPIĆ, J. and MILOSAVLJEVIĆ, M. (2015). Application of the Public-Private Partnership Organizational Structure in the Improvement of Business Operations of Public Sector Enterprises in Serbia. In: Lex Localis - Journal of Local Self-Government. Vol. 13, No. 3, pp.397-417. DOI: http://dx.doi.org/10.4335/13.3.397-417(2015).

BLAGOJEVIĆ, M. and PERIĆ, A. (2021). The Diffusion of Participatory Planning Ideas and Practices: The Case of Socialist Yugoslavia, 1961-

1982. In: Journal of Urban History. pp. 1-24. DOI: http://dx.doi. org/10.1177/00961442211044501.

BOULIANNE, S., CHEN, K. and KAHANE, D. (2020). Mobilizing Mini-

Publics: The Causal Impact of Deliberation on Civic Engagement Using 
Panel Data. In: Politics. Vol. 40, No. 4, pp. 460-47 DOI: http://dx.doi. org/10.1177/0263395720902982.

BRENT, D. A. and LORAH, K. (2019). The Economic Geography of Civic Crowdfunding. In: Cities. Vol. 90, pp. 122-130. DOI: http://dx.doi. org/10.1016/j.cities.2019.01.036.

CABANNES, Y. and LIPIETZ, B. (2017). Revisiting the Democratic Promise of Participatory Budgeting in Light of Competing Political, Good Governance and Technocratic Logics. In: Environment and Urbanization. Vol. 30, No. (1), pp. 67-84. DOI: http://dx.doi.org/10.1177/0956247817746279.

CARÈ, S. et al., (2018). Crowdfunding for the development of smart cities. In: Business Horizons. Vol. 61, No. 4, pp. 501-509. DOI: https://doi. org/10.1016/j.bushor.2017.12.001.

CICVARIĆ KOSTIĆ, S., OKANOVIĆ, M., MILOSAVLJEVIĆ, M. and VUKMIROVIĆ, J. (2013). Antecedents of Citizens' Satisfaction with Local Administration in Serbia. In: Transylvanian Review of Administrative Sciences. Vol. 40E, pp. 22-34. Available at: https://rtsa.ro/tras/index.php/tras/article/ view/141.

DAVIES, R. (2014). Three provocations for civic crowdfunding. In: Information, Communication \& Society. Vol. 18, No. 3, pp. 342-355. DOI: https://doi.org/10.1080/1369118X.2014.989878.

ĐULABIĆ, V. and JERINIĆ, J. (2021). Public Participation in Local Public Action in Croatia and Serbia. In: SSRN Electronic Journal. DOI: http:// dx.doi.org/10.2139/ssrn.3862802.

EWENS, H. and VAN DER VOET, J. (2019). Organizational Complexity and Participatory Innovation: Participatory Budgeting in Local Government. In: Public Management Review. Vol. 21, No. 12, pp. 1848-1866. DOI: http://dx.doi.org/10.1080/14719037.2019.1577908.

FUNG, A. (2015). Putting the Public Back into Governance: The Challenges of Citizen Participation and Its Future. In: Public Administration Review, Vol. 75, No. 4, pp. 513-522. DOI: http://dx.doi.org/10.1111/puar.12361.

GASTIL, J. and XENOS, M. (2010). Of Attitudes and Engagement: Clarifying the Reciprocal Relationship Between Civic Attitudes and Political Participation. In: Journal of Communication. Vol. 60, No. 2, pp. 318-343. DOI: http://dx.doi.org/10.1111/j.1460-2466.2010.01484.x.

HEMER, J. (2011). A Snapshot on Crowdfunding. [online]. Karlsruhe: Fraunhofer-Institut für System - und Innovationsforschung ISI. Available at: https://www.econstor.eu/bitstream/10419/52302/1/671522264. pdf. [Accessed December 20, 2021]. 
JABOLA-CAROLUS, I. (2017). Growing Grassroots Democracy: Dynamic Outcomes in Building New York City's Participatory Budgeting Program. In: New Political Science. Vol. 39, No. 1, pp. 109-125. DOI: http://dx.doi. org/10.1080/07393148.2017.1278857.

JOHNSON, C., CARLSON, H. J. and REYNOLDS, S. (2021). Testing the Participation Hypothesis: Evidence from Participatory Budgeting. In: Political Behavior. DOI: http://dx.doi.org/10.1007/s11109-02109679-w.

KIM, S. ed. (2014). Citizen participation, transparency, and public trust in Government: Participatory budgeting in local governments of Korea. KDI Research Monograph. DOI: https://doi.org/10.22740/kdi.rm.e.2014.03. LAW ON LOCAL SELF-GOVERNMENT (2007). Official Gazette of the Republic of Serbia, No. 129/2007. Available at: https://www.paragraf.rs/propisi/ zakon_o_lokalnoj_samoupravi.html [Accessed December 7, 2021].

LEE, C. H. et al. (2019). Examining the Role of Narratives in Civic Crowdfunding: Linguistic Style and Message Substance. In: Industrial Management \& Data Systems. Vol. 119, No. 7, pp. 1492-1514. DOI: http:// dx.doi.org/10.1108/imds-08-2018-0370.

MACHT, S. A. and WEATHERSTON, J. (2014). The Benefits of Online Crowdfunding for Fund-Seeking Business Ventures. In: Strategic Change. Vol. 23, No. 1-2, pp. 1-14. DOI: http://dx.doi.org/10.1002/jsc.1955.

MÆRØE, A. R. et al., (2020). Increasing Citizen Participation in e-Participatory Budgeting Processes. In: Journal of Information Technology \& Politics. Vol. 18, No. 2, pp. 125-147. DOI: http://dx.doi.org/10.1080/19331681.2020 .1821421.

MAHMOUDI, M. R. et al., (2021). Principal Component Analysis to Study the Relations Between the Spread rates of COVID-19 in High Risks Countries. In: Alexandria Engineering Journal. Vol. 60, No. 1, pp. 457-464. DOI: http://dx.doi.org/10.1016/j.aej.2020.09.013.

MILANOVIĆ, N., MILOSAVLJEVIĆ, M. and MILOŠEVIĆ, N. (2019). Failure Management Approaches and Public Service Quality: Empirical Evidence from Serbia. In: Lex Localis - Journal of Local Self-Government. Vol. 17, No. 3, pp. 417-434. DOI: http://dx.doi.org/10.4335/17.3.417-433(2019). MILOSAVLJEVIĆ, M. et al., (2020). Participatory Budgeting in Serbia: Lessons Learnt from Pilot Projects. In: Lex Localis-Journal of LocalSelf-Government. Vol. 18, No. 4, pp. 999-1021. DOI: http://dx.doi.org/10.4335/18.3.9991021(2020).

MILOSAVLJEVIĆ, M., DOBROTA, M. and MiLANOVIĆ, N, (2018). A New Approach to the Evaluation of Public Procurement Efficiency among 
European Countries. In: European Review. Vol. 27, No. 02, pp. 246-259. DOI: http://dx.doi.org/10.1017/s1062798718000777.

MILOSAVLJEVIC, M., MILANOVIC, N. and BENKOVIC, S. (2017). Waiting for

Godot: Testing Transparency, Responsiveness, and Interactivity of Serbian

Local Governments. In: Lex Localis - Journal of Local Self-Government. Vol. 15, No. 3, pp. 513-528. DOI: http://dx.doi.org/10.4335/15.3.513528(2017).

MILOSAVLJEVIĆ, M., MILANOVIĆ, N., SPASENIĆ, Ž. and BENKOVIĆ, S. (2021).

Civic Crowdfunding: Systematic Literature Re-view and Future Research Agenda. In: E-Business Technologies. Vol. 1, No. 1, p. 125-130. [online] Available at: https://ebt.rs/journals/index.php/conf-proc/article/ view/70.

MILOSAVLJEVIC, M., SPASENIC, Z. and BENKOVIC, S. (2022). Participatory Budgeting in Serbia, in De Vries, M.S., Nemec, J., and Špaček, D. eds. International Trends in Participatory Budgeting. Cham: Palgrave MacMillan. DOI: https://doi.org/10.1007/978-3-030-79930-4_12.

MINÁRIK, P. (2020). Participatory Budgeting and Traditional Participation in Czech Municipalities. In: SlovakJournal of Political Sciences. Vol. 20, No. 1, pp. 29-47. DOI: http://dx.doi.org/10.34135/sjps.200102.

NASTIĆ, M. (2020). Local Elections in Serbia. A Critical Overview. In: Studia Wyborcze. Vol. 30, pp. 113-125. D0I: http://dx.doi.org/10.26485/ sw/2020/30/6.

PANDEYA, G. P. and SHRESTHA, S. K. (2016). Does Citizen Participation Improve Local Planning? An Empirical Analysis of Stakeholders' Perceptions in Nepal. In: Journal of South Asian Development. Vol. 11, No. 3, pp. 276-304. DOI: http://dx.doi.org/10.1177/0973174116667097.

PAVLOVIĆ, D. (2019). The Political Economy Behind the Gradual Demise of Democratic Institutions in Serbia. In: Southeast European and Black Sea Studies. Vol. 20, No. 1, pp. 19-39. DOI: http://dx.doi.org/ 10.1080/14683857.2019.1672929 .

PODLIPNIK, J. and ILIĆ-POPOV, G. (2018). Self-Imposed Contribution in Slovenian and Serbian Legislation: Concept and Legal Nature. In: Lex Localis - Journal of Local Self-Government. Vol. 16, No. 3, pp. 613-630. DOI: http://dx.doi.org/10.4335/16.3.613-630(2018).

RADONIĆ, M. and MILOSAVLJEVIĆ, M. (2019). Human Resource Practices, Failure. Management Approaches and Innovations in Serbian Public Administration. In: Transylvanian Review of Administrative Sciences. Special Issue 2019. pp. 77-93. DOI: http://dx.doi.org/10.24193/tras. si2019.5. 
RADONIC, M., VUKMIROVIC, V. and MILOSAVLJEVIC, M. (2021). The Impact of Hybrid Workplace Models on Intangible Assets: The Case of an Emerging Country. In: Amfiteatru Economic. Vol. 23, No. 58, pp. 770-786. DOI: http://dx.doi.org/10.24818/ea/2021/58/770.

SCHMIDTHUBER, L. and HILGERS, D. (2017). Unleashing Innovation beyond Organizational Boundaries: Exploring Citizensourcing Projects. In: International Journal of Public Administration. Vol. 41, No. 4, pp. 268-283. DOI: http://dx.doi.org/10.1080/01900692.2016.1263656.

SEDLITZKY, R. and FRANZ, Y. (2019). 'What if We All Chip In?' Civic Crowdfunding as Alternative Financing for Urban Development Projects. In: Built Environment. Vol. 45, No. 1, pp. 26-44. DOI: https://doi. org/10.2148/benv.45.1.26.

SILVA, V. B. S. and MORAIS, D. C. (2011). A New Voting Procedure to Support Participatory Budgeting: An Approach Based on the Fuzzy Social Choice. In: 2011 IEEE International Conference on Systems, Man, and Cybernetics. pp. 3184-3189 [online] DOI: http://dx.doi.org/10.1109/ icsmc.2011.6084159.

SINGLA, A., SHUMBERGER, J. and SWINDELL, D. (2019). Paying for infrastructure in the Post-Recession Era: Exploring the Use of Alternative Funding and Financing Tools. In: Journal of Urban Affairs. Vol. 43, No. 4, pp. 526-548. DOI: http://dx.doi.org/10.1080/07352166.2019.1660580

SINTOMER, Y., HERZBERG, C. and RÖCKE, A. (2008). Participatory Budgeting in Europe: Potentials and Challenges. In: International Journal of Urban and Regional Research. Vol. 32, No. 1, pp. 164-178. DOI: http://dx.doi. org/10.1111/j.1468-2427.2008.00777.x.

SKGO. (2006). Građansko učešće na lokalnom nivou: Analiza pravnih okvira i politike uSrbiji i drugim evropskim zemljama. [online] Available at: http:// skgo.org/storage/app/uploads/public/152/095/840/1520958409_ Gradjansko_ucesce_na_lokalnom_nivou.pdf. [Accessed 20 October, 2021] SPIRIĆ, D. (2010). Analiza sistema nadzora Skupštine jedinice lokalne samouprave nad sprovođenjem budžeta. In: Stalna konferencija gradova $i$ opština. [online] Available at: http://mail.skgo.org/storage/app/ uploads/public/152/095/908/1520959080_Analiza_sistema_nadzora Skupstine_lokalne_samouprave_web.pdf. [Accessed 20 October, 2021] STIVER, A. et al., (2014). Civic Crowdfunding Research: Challenges, Opportunities, and Future Agenda. In: New Media \& Society. Vol. 17, No. 2, pp. 249-271. DOI: http://dx.doi.org/10.1177/1461444814558914. 
ŠVALJEK, S., RAŠIĆ BAKARIĆ, I. and SUMPOR, M. (2019). Citizens and the City: The Case for Participatory Budgeting in the City of Zagreb. In: Public Sector Economics. Vol. 43, No. 1, pp. 21-48. DOI: https://doi.org/10.3326/ pse.43.1.4

SWANER, R. (2017). Trust Matters: Enhancing Government Legitimacy through Participatory Budgeting. In: New Political Science. Vol. 39, No. 1, pp. 95-108. DOI: http://dx.doi.org/10.1080/07393148.2017.1278856.

THE OFFICE FOR THE INFORMATION TECHNOLOGIES AND EGOVERNMENT

OF THE REPUBLIC OF SERBIA. (2021). A Budget Plan of the Cities and Municipalities of Serbia. [online] Available at: https://budzeti.data.gov. rs/ [Accessed 20 October, 2021]

TOUCHTON, M., WAMPLER, B. and SPADA, P. (2019). The digital revolution and governance in Brazil: Evidence from participatory budgeting. In: Journal of Information Technology \& Politics. Vol. 16, No. 2, pp. 154-168. DOI: http://dx.doi.org/10.1080/19331681.2019.1613281.

WENZLAFF, K. (2020). Civic Crowdfunding: Four Perspectives on the Definition of Civic Crowdfunding. In: Shneor, R., Zhao, L., and Flåten, B. T. eds. Advances in Crowdfunding: Research and Practice. Palgrave Macmillan, Cham. pp.441-472. DOI: https://doi.org/10.1007/978-3030-46309-0

WILKINSON, C. et al., (2019). In participatory budgeting we trust? Fairness, tactics and (in)accessibility in participatory governance. In: Local Government Studies. Vol. 45, No. 6, pp. 1001-1020. DOI: http://dx.doi.org /10.1080/03003930.2019.1606798.

YANG, K. and PANDEY, S. K. (2011). Further Dissecting the Black Box of Citizen Participation: When Does Citizen Involvement Lead to Good Outcomes? In: Public Administration Review. Vol. 71, No. 6, pp. 880-892. DOI: http://dx.doi.org/10.1111/j.1540-6210.2011.02417.x.

ZEPIC, R., DAPP, M. and KRCMAR, H. (2017). Reasons for Low Participation in German Participatory Budgeting: A Public Administration Perspective. In: Proceedings of the 17th European Conference on Digital Government. Lisbon: Academic Conferences Limited. pp. 262-269. 